Kapata Arkeologi, 12(2), 175-190

ISSN (cetak): 1858-4101

ISSN (elektronik): 2503-0876

http://kapata-arkeologi.kemdikbud.go.id

\title{
SIMBOLISME KOMPLEKS BANGUNAN SITUS KI BUYUT TRUSMI CIREBON
}

\section{Symbolism of Complex Buildings in The Site of Ki Buyut Trusmi Cirebon}

\author{
Muhammad Al Mujabuddawat \\ Balai Arkeologi Maluku - Indonesia \\ Jl. Namalatu-Latuhalat, Ambon 97118 \\ mujab@kemdikbud.go.id
}

Naskah diterima: 17/09/2016; direvisi: 18/11 - 14/12/2016; disetujui: 16/12/2016

Publikasi ejurnal: 30/12/2016

\begin{abstract}
Ki Buyut Trusmi Site is a burial site bounded by walls surrounding the complex site. In the complex area of the site, several buildings scattered in the barrier wall of the spatial division sites as many as 4 cemetery yard; West, East, Central, and North. The buildings are in the midst of hundreds of tombs in the complex area of the site. Based on the results of an overview of the physical form and position of the object of those buildings, it is understood that every buildings has its function and symbolic meaning. The position of the components of the building symbolically form a plan groove toward the main location of the most sanctified, the graves of Ki Gede Trusmi and Prince Trusmi in North yard site. Based on symbolic significance and hundred of tombs scattered in the area of the site, they are clearly show a blend of Islamic buildings affected by local culture which already existed, with the animism and Hindu-Buddhist. Those cultural blends form a pre-Islamic cultural treasures material which tangible on the architecture of the building full of symbolism outside the real Islamic law. Local culture become part of construction to the Islamization of local communities, Islam developed in the area Trusmi shows Islamic character integrative and accommodating to the local indigenous community.
\end{abstract}

Keywords: Site of Ki Buyut Trusmi, Cirebon, kabuyutan, ancient Islam buildings, tombs

\begin{abstract}
Abstrak
Situs Ki Buyut Trusmi merupakan situs pemakaman yang dibatasi oleh tembok keliling yang mengelilingi kompleks situs. Dalam area kompleks situs, berdiri sejumlah bangunan yang tersebar dalam sekat-sekat tembok pembagian halaman situs sebanyak 4 halaman, yaitu Halaman barat, Halaman timur, Halaman tengah, dan Halaman utara. Bangunanbangunan tersebut berdiri ditengah-tengah ratusan makam di dalam area kompleks situs. Berdasarkan hasil tinjauan terhadap bentuk fisik dan keletakan dari objek bangunanbangunan tersebut, diketahui memiliki fungsi dan makna simbolik tersendiri. Keletakan komponen-komponen bangunannya secara simbolis membentuk denah alur menuju lokasi utama yang paling disucikan, yaitu makam Ki Gede Trusmi dan Pangeran Trusmi di Halaman utara situs. Berdasarkan makna simbolik yang ditemukan, serta ratusan makam yang tersebar di dalam area situs tampak jelas menunjukkan percampuran antara bangunan Islam yang terbawa pengaruh budaya lokal yang sebelumnya telah ada, yaitu animisme dan Hindu-Budha. Percampuran tersebut membentuk khasanah budaya materi pra Islam berujud pada arsitektur bangunan yang sarat akan simbolisme di luar syariat Islam yang sesungguhnya. Budaya lokal menjadi bagian konstruksi ke Islaman masyarakat setempat, Islam yang berkembang pada khususnya di daerah Trusmi, Cirebon menunjukkan karakter Islam yang integratif dan akomodatif terhadap paham dan kepercayaan lokal masyarakat.
\end{abstract}

Kata kunci: Situs Ki Buyut Trusmi, Cirebon, kabuyutan, bangunan Islam kuno, makam 


\section{PENDAHULUAN}

Kompleks Situs Ki Buyut Trusmi merupakan kompleks bangunan kuno yang terletak di Kampung Dalem, Desa Trusmi Wetan, Kecamatan Weru, Kabupaten Cirebon. Secara geografis, Situs ini terletak di koordinat $06^{\circ} 41^{\prime}$ 59,8' ' LS dan $108^{\circ} 30^{\prime} 48^{\prime \prime}$ BT (Mujabuddawat, 2015: 140). Situs Ki Buyut Trusmi terdaftar sebagai peninggalan sejarah dan purbakala di Direktorat Jenderal Kebudayaan dengan nomor inventaris 1136 (Soekatno, 1981: 141). Kompleks Situs Ki Buyut Trusmi memiliki luas tanah sekitar 8.100 $\mathrm{m}^{2}$ dan luas bangunan sekitar $500 \mathrm{~m}^{2}$ (Muliawan, 2008: 117). Situs ini dibatasi oleh tembok bata merah setinggi kurang lebih 120 cm (Casta \& Taruna, 2007: 37) dan memiliki 2 gerbang sebagai pintu masuk di sebelah barat dan timur. Kompleks situs ini terdapat sejumlah benda dan bangunan yang berdiri di dalamnya.

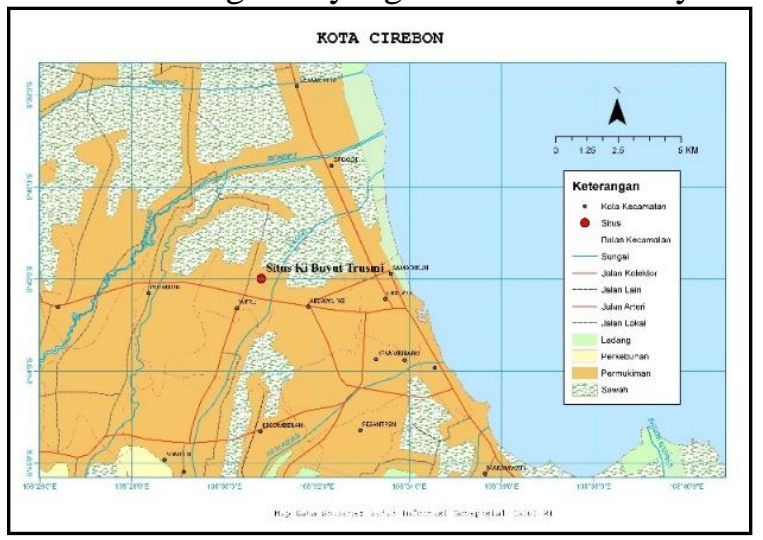

Gambar 1. Peta Lokasi Situs Ki Buyut Trusmi (Sumber: Map Extraction peta dasar BIG, diolah oleh Mujabuddawat, 2015)

Kompleks Situs Ki Buyut Trusmi tergolong dalam kompleks situs pemakaman karena banyak makam kuno dan makam warga sekitar Trusmi di dalam area kompleks situs. Bangunan-bangunan kuno di dalam area kompleks situs berdiri di tengah-tengah ratusan makam yang tersebar di seluruh area kompleks situs. Makam-makam yang tersebar di dalam area kompleks situs merupakan makam tokohtokoh yang dihormati atau diistimewakan. Sebaliknya, makam-makam warga sekitar Trusmi terletak di luar area kompleks situs.

Situs Ki Buyut Trusmi merupakan situs pemakaman terpenting kedua di Cirebon setelah Situs Astana Gunung Jati. Hal ini dapat dilihat dari banyaknya peziarah dan ritual keagamaan di situs ini (Muhaimin, 2006: 185). Pada bagian sudut timur laut kompleks situs ini terdapat bangunan makam yang dikeramatkan dan diistimewakan, yaitu makam Ki Gede Trusmi dan Pangeran Trusmi, yaitu cucu dari Pangeran Cakrabuana. Pangeran Carbon Girang yang merupakan putera dari Pangeran Cakrabuana menikah dengan Nyai Cupluk, puteri Ki Gede Trusmi lalu memiliki anak bernama Pangeran Trusmi yang tinggal di Trusmi (Muhaimin, 2006: 188). Keberadaan kedua makam inilah yang membuat situs ini dikeramatkan dan hingga kini mengundang peziarah yang datang dari wilayah Cirebon dan sekitarnya karena Pangeran Trusmi dan Ki Gede Trusmi merupakan penyiar agama Islam di daerah ini (Mujabuddawat, 2015: 141).

Situs Ki Buyut Trusmi merupakan salah satu situs kepurbakalaan tertua di Pesisir Utara Jawa (Tjandrasasmita, 1976: 8). Situs Ki Buyut Trusmi yang termasuk ke dalam situs pemakaman cukup mewakili bentuk-bentuk makam Islam. Hal tersebut dapat dijumpai dengan keberadaan makam-makam yang berbentuk persegi panjang, berorientasi utaraselatan, serta memiliki tiga unsur yang menjadi kelengkapan satu dengan lainnya, yaitu jirat, nisan, dan cungkup (Ambary, 1998: 199). Situs Ki Buyut Trusmi merupakan salah satu dari 112 situs Kabuyutan yang ada di Kabupaten Cirebon. Situs Kabuyutan dikenal sebagai objek yang sering dikunjungi masyarakat untuk berziarah dan biasanya berupa makam atau lokasi yang dikeramatkan (Saptono, 2013: 183). Situs kabuyutan merupakan sesuatu yang bersifat fisik (bentuk) maupun abstrak (ideologi). Dalam artian sebagai tempat yang disucikan atau dikeramatkan oleh segolongan masyarakat tertentu di Jawa Barat saat ini, di dalamnya terdapat sejumlah artefak dan atau fitur keagamaan dari masa lalu, baik berupa sisa-sisa bangunan suci atau bukan (makam, mata air, gua, bangunan teras berundak, candi, altar, dan objek keramat lainnya), sehingga kabuyutan merupakan sebutan umum untuk menyebut sesuatu yang berkenaan dengan tempat dan dianggap terlarang (Saringendyanti, 1998: 23).

Masyarakat menganggap bahwa makam adalah bagian sakral yang tidak terpisahkan dalam kehidupan, yang merupakan pengaruh pemikiran pra Islam. Makam masih mendapatkan perlakuan yang berlebihan, hal ini erat hubungannya dengan kharisma tokoh yang 
dimakamkan. Tokoh-tokoh tersebut dianggap dapat melindungi kehidupan mereka (Latifundia, 2013: 22). Sisa-sisa pemujaan yang tidak terdapat dalam ajaran Islam masih terlihat dalam masyarakat, makam dianggap sebagai tempat keramat, tempat yang dianggap suci dan dapat membawa keberuntungan melalui ritual. Pengaruh positif yang muncul yaitu terpeliharanya makam-makam kuno dengan unsur-unsur penanda makam lainnya (Latifundia, 2015: 40).

Wajah Islam Nusantara yang akomodatif bisa ditelusuri dari sejarah interaksi Islam yang secara faktual turun di Tanah Hijaz, sebuah wilayah yang letaknya ribuan kilometer dari Nusantara yang telah ratusan tahun memeluk keyakinan animisme, dinamisme, kemudian Hindu dan Budha sebagai kepercayaan yang telah ada sebelum kedatangan Islam (Darajat, 2015: 68). Bentuk perkembangan sosial budaya masyarakat diantaraya adalah aspek religi, dari perkembangan religi masa pra agama hingga munculnya agama Islam. Tradisi kepercayaan lokal hingga munculnya Islam, sesungguhnya dapat diidentifikasi berdasarkan tinggalan arkeologisnya. Bentuk-bentuk akomodatif Islam dengan budaya lokal, dalam berbagai aspek dapat ditinjau dari karakteristik budaya material yang dihasilkan baik itu berbentuk bangunan atau fitur, maupun data artefaktual (Handoko, 2012: 27). Hasil penelitian arkeologi menjadi domain yang penting untuk mengungkap sejarah budaya, terutama soal bagaimana perkembangan Islam dalam periode tertentu yang kurang terangkat dalam studi sejarah, misalnya tentang dinamika Islam dan budaya lokal melalui analisis serangkaian data artefaktual maupun situs yang dapat membantu melengkapi informasi sejarah (Handoko, 2014: 44).

Islam di Nusantara sangat akomodatif terhadap tradisi lokal, banyak pengamat yang menilai Islam di Nusantara sebagai Islam sinkretis, Islam periferal, atau sebutan lainnya yang menggambarkan betapa Islam di Nusantara bukanlah Islam yang sesungguhnya dibandingkan dengan Islam di Timur Tengah. Islam di Nusantara lebih banyak didominasi tradisi dan sistem kepercayaan lokal yang terkadang tidak sesuai dengan ajaran Islam sesungguhnya, sehingga menurut (Darajat, 2015: 70) mengarah kepada praktik-praktik takhayul, bid'ah, dan khurafat. Warisan budaya
Islam Nusantara berujud pada material peradaban seperti berbagai ragam bangunan, antara lain masjid, bangunan keraton, dan makam (Darajat, 2015: 77).

Kompleks Situs Ki Buyut Trusmi terbagi atas empat ruang, yaitu Halaman barat, Halaman timur, Halaman tengah, dan Halaman utara. Pada setiap bagian-bagian ruang tersebut terdapat bangunan-bangunan yang berdiri di dalamnya dengan beragam fungsi. Arsitektur merupakan bagian sistem tata nilai suatu masyarakat, yang menjadi cermin tata nilai tersebut yang berujud bangunan dan strukturstruktur yang ada (Anonim, 1993: 35). Begitu pun dengan sejumlah bangunan yang berdiri di dalam areal keruangan situs ini, memiliki fungsi dan makna yang dapat dilihat dari bentuknya.

Sejumlah bangunan yang berada di kompleks situs Ki Buyut Trusmi sesungguhnya merupakan bangunan-bangunan pendukung untuk melengkapi bangunan utama yang dikeramatkan, yaitu makam Ki Gede Trusmi dan Pangeran Trusmi. Bentuk bangunan yang berada pada kompleks situs ini memiliki ciri budaya lokal yang tentu saja merupakan bentuk budaya pra Islam yang secara fisik tidak menyerupai bangunan Islam yang sesuai syariat. Secara historis perkembangan Islam dalam bentuk budaya material di setiap wilayah akan memperlihatkan ciri dan karakter yang beragam (Latifundia, 2014: 102). Budaya pra Islam dapat dilihat pada peninggalanpeninggalan masa animisme dan dinamisme hingga masa Hindu dan Budha yang sudah diterima di dalam masyarakat sebelum datangnya Islam. Pada akhir masa HinduBudha di Jawa pada umumnya dan di Tatar Sunda khususnya terdapat bentuk budaya masa prasejarah (budaya lokal) yang muncul kembali serta berakulturasi dengan budaya Hindu-Budha dan Islam (Saptono, 2013: 192). Budaya pra Islam sarat akan bentuk-bentuk simbolisme atau kepercayaan-kepercayaan tertentu namun terdapat usaha dalam penyesuaian dengan bentuk syariat Islam. Pengertian simbolisme dalam hal ini ialah adanya makna atau kepercayaan tertentu yang diterapkan dalam bentuk ragam bangunan yang berdasar pada kebiasaan dan budaya setempat. Begitu pula dengan tata letak bangunan dalam konteks hubungan pembagian empat ruang kompleks situs yang bila ditinjau dari bentuk budaya pra Islam memiliki makna simbolis tertentu. 
Tulisan ini membahas dua hal, yaitu 1) fungsi dan makna simbolik dari ragam bentuk bangunan di dalam area keruangan Ki Buyut Trusmi, 2) makna simbolik dari denah tata letak kompleks situs $\mathrm{Ki}$ Buyut Trusmi secara keseluruhan. Tujuan penelitian ini ialah meninjau fungsi dan makna simbolik dari bangunan-bangunan yang berdiri di dalam area keruangan kompleks situs, serta menafsirkan makna simbolik dari denah tata letak kompleks situs Ki Buyut Trusmi secara keseluruhan.

\section{METODE}

Penelitian di dalam tulisan ini menggunakan metode kualitatif arkeologi dengan beberapa tahapan, yaitu observasi, deskripsi, dan penafsiran (Deetz, 1967: 8). Tahap observasi berupa pengumpulan data-data referensial, yaitu data pustaka dan data lapangan berupa foto dan hasil wawancara. Setelah itu dilakukan pencatatan dari hasil pengamatan dalam bentuk deskripsi terhadap objek kajian baik objek lokus penelitian maupun beberapa situs di sekitar Trusmi yang memiliki kemiripan sebagai bahan perbandingan. Pada tahap deskripsi atau pengolahan data, dilakukan analisis terhadap data yang dikumpulkan. Data pustaka digunakan untuk memperkuat analisis data lapangan hingga menghasilkan penafsiran untuk menjawab pertanyaan penelitian.

\section{HASIL DAN PEMBAHASAN}

Kompleks Situs Ki Buyut Trusmi terbagi atas empat ruang, yaitu Halaman barat, Halaman timur, Halaman tengah, dan Halaman utara. Pembahasan di dalam tulisan ini dibagi berdasarkan pembagian pola keruangan tersebut.

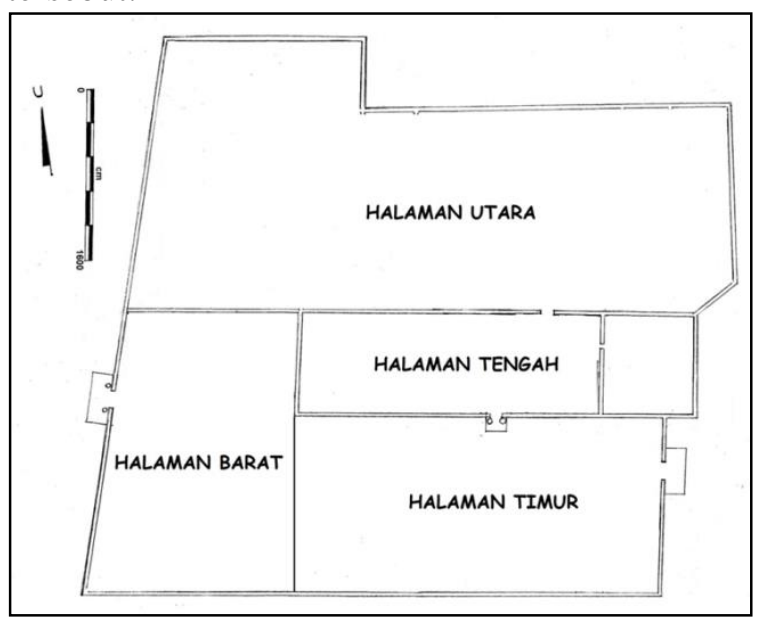

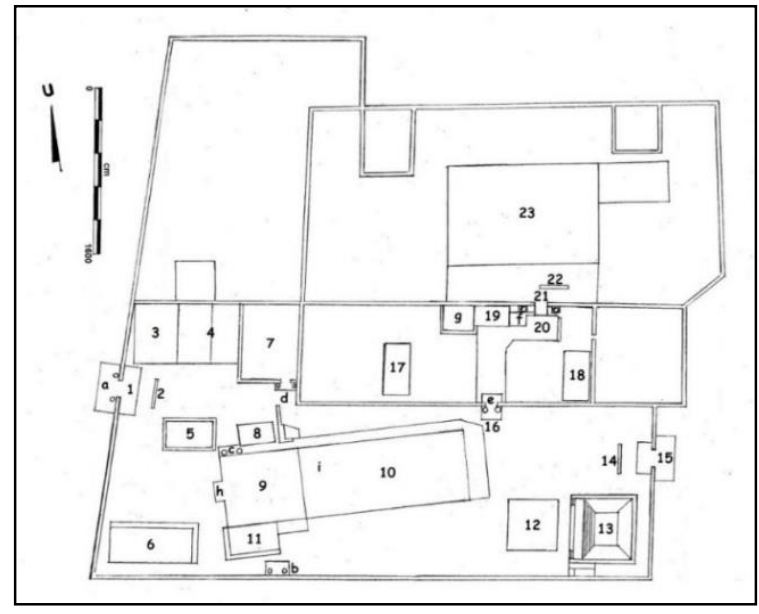

Gambar 2. Denah ruang Kompleks Situs Ki Buyut Trusmi

(Sumber: Mujabuddawat, 2013)

Tabel 1. Keterangan gambar 2

\begin{tabular}{|c|c|c|c|}
\hline 1 & Gerbang kori agung (a) & $\mathrm{a}$ & Padasan (a),(b) \\
\hline 2 & Kuta hijab (a) & $\mathrm{b}$ & Padasan wudhu (a),(b) \\
\hline 3 & Bale pakuncen & $\mathrm{c}$ & Padasan wudhu (c),(d) \\
\hline 4 & Bale paseban & $d$ & Padasan (c),(d) \\
\hline 5 & Pendopo & $\mathrm{e}$ & Padasan $(\mathrm{e}),(\mathrm{f})$ \\
\hline 6 & Pewadonan & $f$ & Padasan $(\mathrm{g}),(\mathrm{h})$ \\
\hline 7 & Pemakaman kepundungan & $\mathrm{g}$ & watu pendadaran \\
\hline 8 & Tempat wudhu dan sumur & $\mathrm{h}$ & mimbar masjid \\
\hline 9 & Ruang utama masjid & $\mathrm{i}$ & bedug \\
\hline 10 & Serambi masjid & & \\
\hline 11 & Pawestren & & \\
\hline 12 & Witana & & \\
\hline 13 & Pekulahan & & \\
\hline 14 & Kuta hijab (b) & & \\
\hline 15 & Gerbang kori agung (b) & & \\
\hline 16 & Gerbang kori agung (c) & & \\
\hline 17 & Jinem kulon & & \\
\hline 18 & Jinem wetan & & \\
\hline 19 & Bale pesalinan & & \\
\hline 20 & Ruang peziarah & & \\
\hline 21 & Gerbang kori agung (d) & & \\
\hline 22 & Kuta hijab & & \\
\hline 23 & Makam Ki Buyut Trusmi & & \\
\hline & er: Mujabuddawat, & & \\
\hline
\end{tabular}

Fungsi dan Makna Simbolik Bangunan di Halaman barat

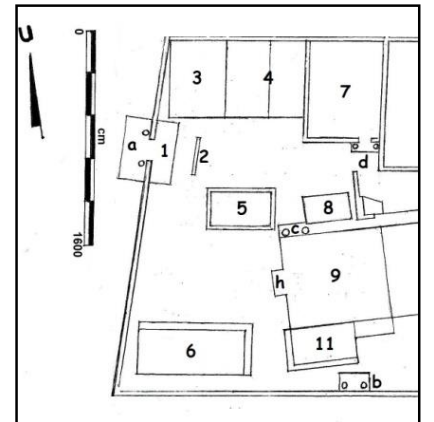

Gambar 3. Keletakan sebaran bangunan Halaman barat

(Sumber: Mujabuddawat, 2013) 
Area Halaman barat terdiri atas 10 objek

bangunan sebagai berikut.

Tabel 2. Bangunan Halaman barat

\begin{tabular}{ll}
\hline No & Bangunan \\
\hline 1 & Gerbang kori agung (a) \\
\hline 2 & Kuta hijab (a) \\
\hline 3 & Lawang kepundungan \\
\hline 4 & Bale paseban \\
\hline 5 & Bale pakuncen \\
\hline 6 & Pendopo \\
\hline 7 & Tempat wudhu \\
\hline 9 & Pewadonan \\
\hline 10 & Ruang utama masjid \\
\hline Sumber: & Majabuddawat, 2013
\end{tabular}

Seluruh area ke ruangan kompleks situs Ki Buyut Trusmi dibatasi oleh tembok keliling setinggi $150 \mathrm{~cm}$. Tembok keliling kompleks situs Ki Buyut Trusmi berfungsi menjadi dinding pembatas area kompleks situs dengan dunia luar. Tembok ini memanjang mengelilingi kompleks situs seluas $8.100 \mathrm{~m}^{2}$ membentuk denah seperti persegi panjang. Tembok keliling ini menjadi batas area keramat Buyut Trusmi yang melindungi tinggalantinggalan benda dan bangunan yang berdiri di dalamnya (Mujabuddawat, 2013: 60). Keberadaan tembok keliling ini menunjukkan bahwa area yang dikelilingi oleh tembok keliling ini merupakan area penting dan secara simbolik menonjolkan eksklusivitasnya.

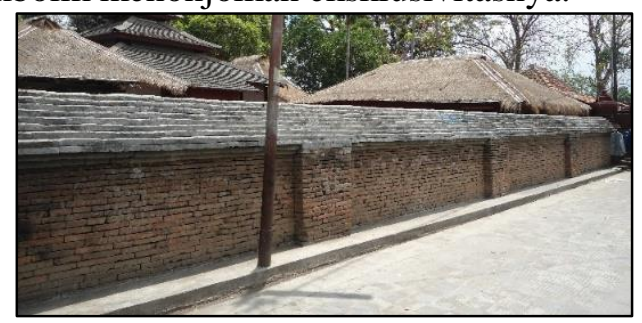

Gambar 4. Tembok keliling Kompleks Situs (Sumber: Mujabuddawat, 2013)

Pada bagian sisi barat kompleks situs terdapat gerbang masuk situs, yaitu gerbang kori agung (a). Berdasarkan keletakan dan bentuknya, gerbang kori agung (a) merupakan pintu masuk utama ke dalam kompleks situs Ki Buyut Trusmi. Gerbang dengan atap penutup disebut paduraksa atau kori agung, merupakan pengembangan dari bentuk gaya arsitektur gerbang sebelumnya yang lebih kuno (Tjandrasasmita, 1975: 46). Padasan (a) dan (b) terletak di hadapan kedua sisi bangunan gerbang kori agung (a). Berdasarkan uraian bentuk yang telah dijabarkan sebelumnya, maka kedua padasan ini berfungsi sebagai penampung air. Berdasarkan fungsi padasan yang terdapat pada bangunan-bangunan Islam kuno di Jawa, padasan ialah gentong atau tempayan dari tanah liat yang berfungsi sebagai tempat air wudhu atau membersihkan diri. Tempat air wudhu merupakan elemen penting dan harus ada pada setiap bangunan masjid di Indonesia (Haris, 2010: 286). Keberadaan padasan secara simbolik mengartikan bahwa siapa pun yang mau memasuki kompleks itu masuk dengan cara berhormat dan dalam keadaan suci. Pengunjung wajib melepas alas kaki sebelum memasuki kompleks situs dan mencuci kakinya dengan air dari padasan. Keberadaan padasan di depan gerbang kori agung (a) secara simbolik menunjukkan bahwa gerbang kori agung (a) merupakan pintu masuk utama ke dalam area keruangan kompleks situs Ki Buyut Trusmi.

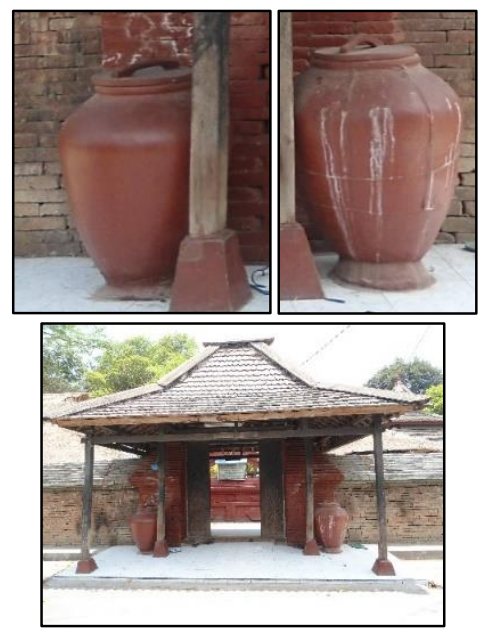

Gambar 5. Padasan (a) \& (b), Gerbang Kori Agung (a)

(Sumber: Mujabuddawat, 2013)

Setelah melewati gerbang kori agung (a) maka akan dihadapkan pada kuta hijab (a). Berdasarkan keletakannya yang berada tepat di balik gerbang kori agung (a), dapat diketahui fungsi dari keberadaan kuta hijab (a) ini ialah sebagai penyekat untuk menghalangi pandangan ke dalam area kompleks situs $\mathrm{Ki}$ Buyut Trusmi yang secara simbolik untuk mencegah masuknya roh jahat. Keberadaan kuta hijab juga merupakan bagian dari konsep pembagian area ruang yang disekat-sekat oleh tembok pembatas yang seringkali ditemukan hingga menunjukkan ciri khas dari kompleks bangunan arkeologi Islam (Anonim, 1993: 37). 


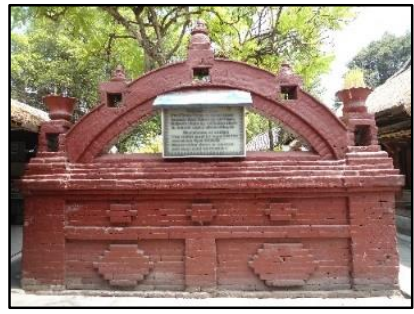

Gambar 6. Kuta Hijab (a)

(Sumber: Mujabuddawat, 2013)

Pada bagian utara kuta hijab (a) terdapat bangunan bale pakuncen dan paseban. Sesuai dengan namanya, 'bale' artinya balai atau rumah dan 'pakuncen' artinya para Kuncen, maka bale pakuncen merupakan bangunan tempat khusus para Juru Kunci dan Kuncen beristirahat dan bertugas sehari-hari. Sedangkan bangunan bale paseban berfungsi sebagai tempat para Juru Kunci untuk bermusyawarah dan menaruh barang. Bentuk bale pakuncen yang terbuka tanpa dinding secara simbolik menunjukkan bahwa bale pakuncen terbuka untuk para pengunjung, serta memudahkan para Kuncen untuk memantau pengunjung yang memasuki kompleks situs Ki Buyut Trusmi.

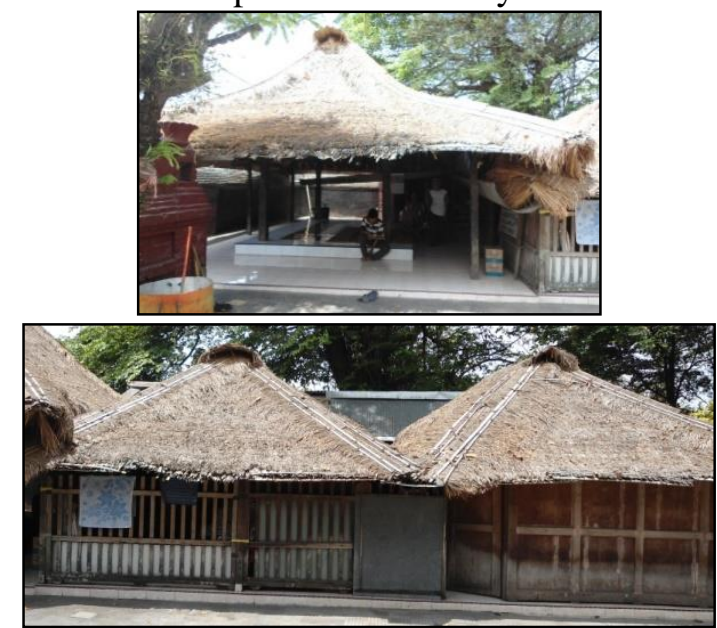

Gambar 7. Bale Pakuncen (atas) dan Bale Paseban (bawah)

(Sumber: Mujabuddawat, 2013)

Bangunan pendopo terletak di sebelah selatan kuta hijab (b) yang berada tepat di balik gerbang kori agung (a) yang berfungsi sebagai pintu masuk utama situs, maka dapat diketahui bangunan pendopo berfungsi sebagai tempat beristirahat bagi tamu dan peziarah yang berkunjung. Didukung pula dengan bentuknya yang tak berdinding menjadikan pendopo sebagai bangunan yang terbuka dan bebas dimasuki oleh siapa pun. Pada bagian sisi timur dari bangunan pendopo berhadapan langsung bangunan tempat wudhu. Dari segi keletakan dan bentuk yang telah diuraikan, maka diketahui bangunan tempat wudhu berfungsi sebagai bangunan yang melindungi sumur dan tempat berwudhu jamaah yang akan melaksanakan ibadah di masjid karena letak bangunan tempat wudhu tepat bersebelahan dengan ruang utama masjid.

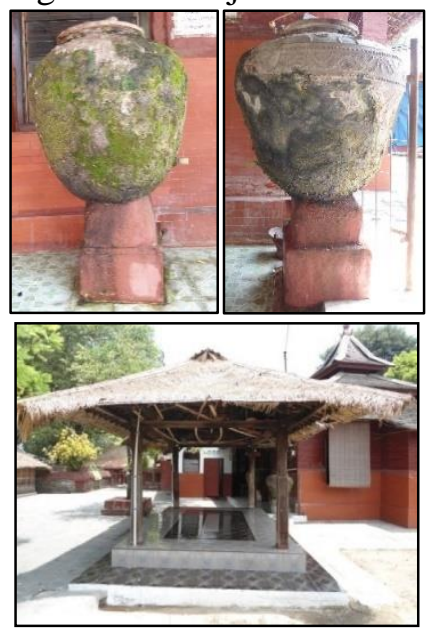

Gambar 8. Padasan air wudhu (c) dan (d), Pendopo (Sumber: Mujabuddawat, 2013)

Pada bagian sisi selatan bangunan pendopo berhimpitan dengan padasan atau tempat air wudhu (c) dan (d). Pada beberapa situs masjid kuno di Nusantara, tempat berwudhu dapat berbentuk kolam air, parit, atau kulah, namun pada beberapa masjid kuno di Jawa antara lain di Masjid Gala dan di masjid Makam Sunan Bayat, di desa Paseban, Kecamatan Tembayat, Kabupaten Klaten, fungsi kolam atau kulah digantikan dengan gentong, atau tempayan dari tanah liat (Jawa: padasan) sebagai tempat air wudhu (Haris, 2010: 286). Berdasarkan uraian bentuk yang telah diuraikan sebelumnya, maka diketahui bahwa padasan berfungsi sebagai wadah yang digunakan untuk menampung air. Lubang corong yang terdapat pada bagian dasar kedua padasan air wudhu ini berfungsi untuk mengalirkan air ke bawah. Kedua padasan air wudhu ini ditinggikan $45 \mathrm{~cm}$ di atas beton untuk disesuaikan dengan ukuran tubuh manusia agar memudahkan jamaah dalam berwudhu. Berdasarkan lokasi keletakan padasan yang berada persis berhimpitan dengan dinding luar sisi utara ruang utama masjid mengartikan secara simbolis bahwa padasan tersebut difungsikan untuk berwudhu para 
jamaah laki-laki secara umum, karena ruang utara masjid adalah tempat ibadah jamaah lakilaki.

Pada sisi selatan di halaman barat terdapat bangunan pewadonan yang berbatasan langsung dengan tembok keliling sisi selatan situs. Berdasarkan penamaannya 'pewadonan' (bahasa Jawa) artinya tempat perempuan. Bangunan ini pun terletak tepat berdekatan dengan bangunan pawestren yang berbatasan langsung sebelah timur dari bangunan pewadonan ini.

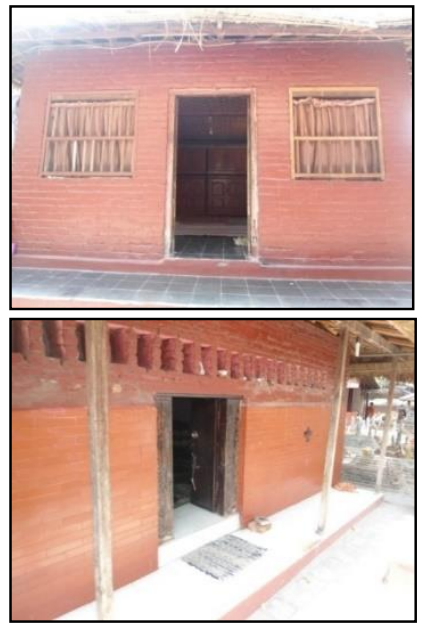

Gambar 9. Pewadonan (atas) dan Pawestren (bawah)

(Sumber: Mujabuddawat, 2013)

Pada sisi timur bangunan paseban berbatasan langsung dengan tembok keliling pemakaman kepundungan. Pemakaman kepundungan merupakan pemakaman yang dikeramatkan oleh masyarakat (Mujabuddawat, 2013: 89). Pemakaman kepundungan ini terletak di dalam area tembok keliling kompleks situs $\mathrm{Ki}$ Buyut Trusmi. Area pemakaman terletak di sebelah utara bangunan ruang utama masjid. Fungsi lawang kepundungan ini ialah sebagai pintu masuk menuju ke dalam area pemakaman kepundungan. Padasan (c) dan (d) terletak di hadapan kedua sisi lawang kepundungan. Berdasarkan uraian bentuk yang telah ditulis sebelumnya, maka kedua padasan ini berfungsi sebagai penampung air yang secara simbolik para pengunjung yang hendak memasuki pemakaman kepundungan agar bersuci terlebih dahulu. Bentuk gerbang lawang kepundungan yang memiliki tinggi $100 \mathrm{~cm}$ berukuran pendek untuk ukuran manusia normal, hingga menyerupai makna simbolik dari gerbang kori agung karena untuk melewatinya harus menunduk sebagai pertanda hormat. Bentuk penghormatan seperti ini merupakan budaya masyarakat lokal yang meninggikan tokoh yang dihormati. Ketika bertemu seorang tokoh yang dihormati dan dituakan, maka sudah menjadi budaya menunduk terlebih dahulu sebagai bentuk sopan santun. Hal tersebut juga diterapkan ketika datang bertamu dan hendak memasuki rumah maka bentuk sopan santun masyarakat ialah dengan cara menundukkan badan. Perilaku tersebut diterapkan dalam wujud bentuk bangunan seperti ini. Dalam hukum syariat Islam, tida ada bentuk penghormatan atau perlakuan berlebih terhadap makam jasad yang telah mati. Makna simbolis penghormatan terhadap makam yang dikeramatkan seperti ini merupakan ciri budaya pra Islam (Latifundia, 2013: 22) yang menurut (Darajat, 2015: 70) sebenarnya tidak sesuai dengan ajaran Islam.

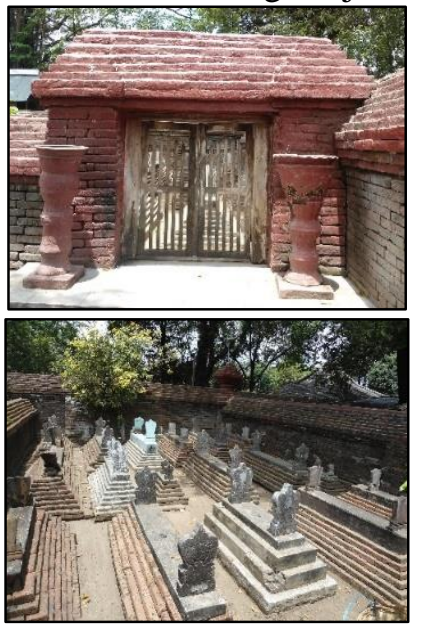

Gambar 10. Lawang Kepundungan, Padasan (c) dan (d) (atas) dan Makam Kepundungan (bawah)

(Sumber: Mujabuddawat, 2013)

Sebelah selatan lawang kepundungan berhadapan dengan bangunan ruang utama masjid. Berdasarkan bentuknya, fungsi bangunan ruang utama masjid merupakan bangunan yang memiliki kelengkapan sebagai masjid tempat umat Islam beribadah. Pada bagian sisi selatan ruang utama masjid, terdapat bangunan pawestren yang menempel langsung dengan bangunan ruang utama masjid. Berdasarkan bentuk dan keletakannya tersebut, fungsi bangunan pawestren ini merupakan bangunan tempat jamaah perempuan beribadah. Terdapat pintu yang menghubungkan antara ruang utama masjid dengan pawestren di sebelah selatan, namun pintu tersebut berukuran 
pendek, tertutup rapat, dan bertirai. Hal tersebut mengandung makna bahwa bangunan pawestren masih terhubung dengan bangunan masjid sehingga kaum perempuan dan laki-laki dapat beribadah berjamaah, namun terdapat batas ruang yang jelas antara ruang untuk lakilaki dan perempuan.

Pada bagian sisi selatan bangunan pawestren, terdapat padasan (a) dan (b). Berdasarkan bentuknya, diketahui fungsi padasan (a) dan (b) merupakan wadah yang digunakan untuk menampung air. Lubang corong yang terdapat pada bagian dasar kedua padasan berfungsi untuk mengalirkan air ke bawah. Kedua padasan ini ditinggikan $50 \mathrm{~cm}$ di atas beton untuk disesuaikan dengan ukuran tubuh manusia agar memudahkan jamaah dalam berwudhu. Berdasarkan lokasi keletakan padasan (a) dan (b) yang berada persis dihadapan bangunan pawestren mengartikan secara simbolis bahwa padasan air wudhu (a) dan (b) difungsikan untuk berwudhu para jamaah perempuan.

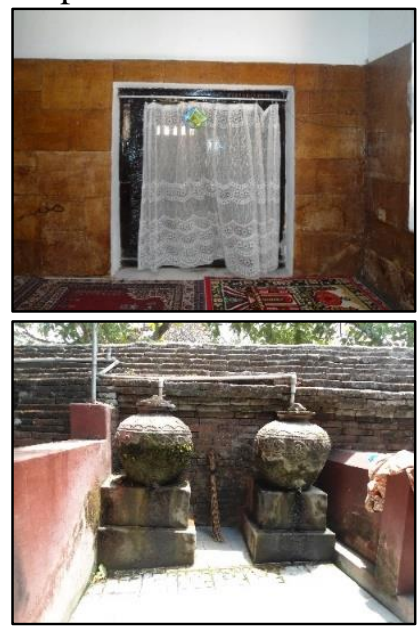

Gambar 11. Pintu yang menghubungkan pawestren dengan bangunan utama Masjid (atas) dan padasan (a) dan (b) (bawah)

(Sumber: Mujabuddawat, 2013)

Secara keseluruhan, berdasarkan fungsi dari setiap objek benda dan bangunan di Halaman barat ini berfungsi sebagai halaman yang menjadi awal masuk pengunjung. Halaman barat situs ini merupakan ruang yang menaungi objek benda dan bangunan yang berfungsi sebagai komponen utama kompleks situs. Karena dari segi fungsi objek, benda dan bangunan di halaman barat ini adalah komponen yang menjadi salah satu tujuan utama kedatangan pengunjung ke Situs ini. Hal tersebut ditunjukkan oleh keberadaan bangunan bale pakuncen yang menjadi tempat perizinan pengunjung, tempat wudhu, ruang utama masjid, pawestren, dan pewadonan yang merupakan sarana untuk ibadah pengunjung.

Tabel 3. Fungsi dan Makna Simbolik Bangunan di Halaman barat

\begin{tabular}{|c|c|c|}
\hline No & Bangunan & Fungsi \& Makna simbolik \\
\hline \multirow[t]{2}{*}{1} & \multirow[t]{2}{*}{$\begin{array}{l}\text { Gerbang kori } \\
\text { agung (a) }\end{array}$} & $\begin{array}{l}\text { Pintu masuk utama area keruangan } \\
\text { kompleks situs }\end{array}$ \\
\hline & & $\begin{array}{l}\text { Menunduk ketika melewati gerbang } \\
\text { yang pendek sebagai pertanda } \\
\text { hormat, membasuh kaki dengan air } \\
\text { dari padasan menandakan kesucian } \\
\text { ruang di balik gerbang ini }\end{array}$ \\
\hline \multirow[t]{2}{*}{2} & \multirow[t]{2}{*}{$\begin{array}{l}\text { Lawang } \\
\text { kepundungan }\end{array}$} & $\begin{array}{l}\text { Sebagai pintu masuk menuju area } \\
\text { makam kepundungan }\end{array}$ \\
\hline & & $\begin{array}{l}\text { Menunduk ketika melewati gerbang } \\
\text { yang pendek sebagai pertanda } \\
\text { hormat, membasuh kaki dengan air } \\
\text { dari padasan menandakan kesucian } \\
\text { ruang di balik gerbang ini }\end{array}$ \\
\hline \multirow[t]{2}{*}{3} & \multirow[t]{2}{*}{$\begin{array}{l}\text { Tembok } \\
\text { keliling situs }\end{array}$} & $\begin{array}{l}\text { Sebagai batas area keruangan situs, } \\
\text { melindungi tinggalan-tinggalan benda } \\
\text { dan bangunan yang berdiri di } \\
\text { dalamnya }\end{array}$ \\
\hline & & $\begin{array}{l}\text { menunjukkan bahwa area yang } \\
\text { dikelilingi oleh tembok keliling ini } \\
\text { merupakan area penting dan secara } \\
\text { simbolik menonjolkan eksklusifitasnya }\end{array}$ \\
\hline 4 & Kuta hijab (a) & $\begin{array}{l}\text { Menyekat antara gerbang masuk yaitu } \\
\text { gerbang kori agung (a) yang } \\
\text { menyambungkan dunia luar dengan } \\
\text { area yang disucikan atau dikeramatkan } \\
\text { begitu melewati kuta hijab (a) supaya } \\
\text { orang dari luar tidak bisa langsung } \\
\text { melihat isi di dalam Situs dan sebagai } \\
\text { penangkal roh jahat }\end{array}$ \\
\hline \multirow[t]{2}{*}{5} & \multirow[t]{2}{*}{$\begin{array}{l}\text { Bale } \\
\text { pakuncen }\end{array}$} & $\begin{array}{l}\text { Sebagai tempat bertugas dan } \\
\text { beristirahat para Juru Kunci situs } \\
\text { Keletakannya dihadapan gerbang kori } \\
\text { agung (a) memudahkan pengunjung } \\
\text { untuk menghadap Juru Kunci untuk } \\
\text { izin, serta memudahkan Juru Kunci } \\
\text { memantau kedatangan pengunjung }\end{array}$ \\
\hline & & $\begin{array}{l}\text { Bentuk bale pakuncen yang terbuka } \\
\text { tanpa dinding secara simbolik } \\
\text { menunjukkan bahwa bale pakuncen } \\
\text { terbuka untuk para pengunjung }\end{array}$ \\
\hline \multirow[t]{2}{*}{6} & \multirow[t]{2}{*}{ Bale paseban } & $\begin{array}{l}\text { Sebagai tempat bermusyawarah dan } \\
\text { menaruh barang para Juru Kunci situs }\end{array}$ \\
\hline & & $\begin{array}{l}\text { Keetakannya bersebelahan dengan } \\
\text { bangunan bale pakuncen menandakan } \\
\text { bangunan bale paseban menjadi ruang } \\
\text { mobilisasi para Juru Kunci }\end{array}$ \\
\hline
\end{tabular}




\begin{tabular}{|c|c|c|}
\hline \multirow[t]{2}{*}{7} & \multirow[t]{2}{*}{ Pendopo } & $\begin{array}{l}\text { Sebagai tempat beristirahat bagi tamu } \\
\text { dan peziarah yang berkunjung }\end{array}$ \\
\hline & & $\begin{array}{l}\text { Bagian alur masuk menuju kompleks } \\
\text { situs Ki Buyut Trusmi sehingga secara } \\
\text { simbolik, pendopo ini berfungsi } \\
\text { sebagai tempat istirahat atau tempat } \\
\text { menunggu para pengunjung yang akan } \\
\text { melakukan ziarah }\end{array}$ \\
\hline \multirow[t]{2}{*}{8} & \multirow[t]{2}{*}{$\begin{array}{l}\text { Tempat } \\
\text { wudhu }\end{array}$} & $\begin{array}{l}\text { Sebagai bangunan yang melindungi } \\
\text { sumur dan tempat berwudhu jamaah } \\
\text { yang akan melaksanakan ibadah }\end{array}$ \\
\hline & & $\begin{array}{l}\text { Secara simbolik menunjukkan alur } \\
\text { yang mengarahkan kepada para } \\
\text { peziarah yang berniat langsung } \\
\text { menuju masjid melaksanakan ibadah } \\
\text { Keberadaan padasan air wudhu (c) dan } \\
\text { (d) yang terletak menjelang pintu } \\
\text { masuk masjid dan ditinggikan dari } \\
\text { permukaan tanah menandakan } \\
\text { padasan ini diperuntukkan untuk } \\
\text { berwudhu jamaah laki-laki }\end{array}$ \\
\hline \multirow[t]{2}{*}{9} & \multirow[t]{2}{*}{ Pewadonan } & $\begin{array}{l}\text { Sebagai tempat tirakat atau menyepi } \\
\text { perempuan }\end{array}$ \\
\hline & & $\begin{array}{l}\text { Secara simbolik bangunan ini sengaja } \\
\text { berdiri berdekatan dengan bangunan } \\
\text { pawestren agar para jamaah } \\
\text { perempuan mudah berpindah ke } \\
\text { ruang aktifitas lainnya setelah } \\
\text { melaksanakan ibadah di pawestren. } \\
\text { Karena pawestren dan pewadonan } \\
\text { letaknya berdekatan, maka membuat } \\
\text { alur khusus jamaah perempuan agar } \\
\text { tidak saling berinteraksi dengan } \\
\text { jamaah laki-laki }\end{array}$ \\
\hline \multirow[t]{2}{*}{10} & \multirow{2}{*}{$\begin{array}{l}\text { Ruang utama } \\
\text { masjid }\end{array}$} & Sebagai tempat umat Islam beribadah \\
\hline & & $\begin{array}{l}\text { Menunjukkan bahwa situs kabuyutan } \\
\text { ini merupakan situs besar yang } \\
\text { diagungkan }\end{array}$ \\
\hline \multirow[t]{2}{*}{11} & \multirow[t]{2}{*}{ Pawestren } & $\begin{array}{l}\text { Sebagai tempat jamaah perempuan } \\
\text { beribadah }\end{array}$ \\
\hline & & $\begin{array}{l}\text { Pintu masuk yang pendek merupakan } \\
\text { pintu khusus yang tidak semua jamaah } \\
\text { bisa keluar masuk melewatinya, } \\
\text { namun hanya jamaah perempuan yang } \\
\text { disimbolkan memiliki postur tubuh } \\
\text { lebih kecil dari laki-laki diterapkan } \\
\text { pada ukuran pintu masuk pawestren } \\
\text { ini } \\
\text { Keberadaan padasan air wudhu (a) } \\
\text { dan (b) yang terletak menjelang pintu } \\
\text { masuk masjid dan ditinggikan dari } \\
\text { permukaan tanah menandakan } \\
\text { padasan ini diperuntukkan untuk } \\
\text { berwudhu jamaah perempuan }\end{array}$ \\
\hline
\end{tabular}

Fungsi dan Makna Simbolik Bangunan di Halaman timur

Area halaman timur terdiri atas objek bangunan sebagai berikut.

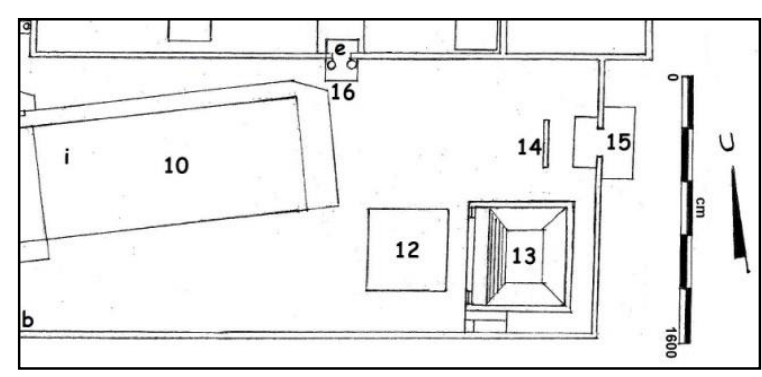

Gambar 12. Keletakan sebaran bangunan Halaman timur

(Sumber: Mujabuddawat: 2013)

Tabel 4. Bangunan halaman timur situs

\begin{tabular}{ll}
\hline No & Bangunan \\
\hline 1 & Gerbang kori agung (b) \\
\hline 2 & Pekulahan \\
\hline 3 & Gerbang kori agung (c) \\
\hline 4 & Kuta hijab (b) \\
\hline 5 & Serambi masjid \\
\hline 6 & Witana \\
\hline Sumber: & Mujabuddawat 2013
\end{tabular}

Sumber: Mujabuddawat 2013

Berbatasan dengan halaman barat situs, langsung dihadapkan oleh bangunan ruang serambi masjid. Fungsi bangunan ruang serambi masjid ini merupakan perluasan dari bangunan ruang utama masjid tempat umat Islam beribadah. Pada bagian sudut timur laut bangunan serambi masjid terdapat gerbang kori agung (c) dengan padasan (e) dan (f) tepat di hadapan gerbang. Berdasarkan keletakannya, dapat diketahui gerbang kori agung (c) merupakan pintu yang menyambungkan antara halaman timur dengan halaman tengah kompleks situs Ki Buyut Trusmi. Sementara itu, padasan (e) dan (f) yang terletak di hadapan kedua sisi bangunan gerbang kori agung (c) berdasarkan bentuknya kedua padasan ini berfungsi sebagai penampung air. Berdasarkan fungsi padasan yang terdapat pada bangunanbangunan Islam kuno di Jawa, padasan ialah gentong atau tempayan dari tanah liat yang berfungsi sebagai tempat air wudhu atau membersihkan diri.

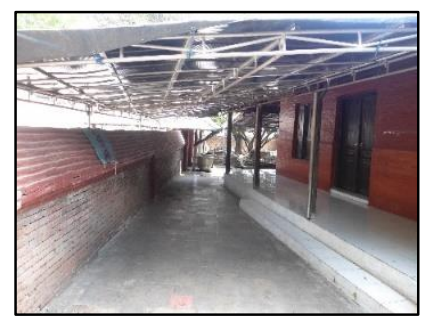

Gambar 13. Pintu masuk sisi utara ruang Serambi Masjid

(Sumber: Mujabuddawat, 2016) 
Dari segi makna simbolik gaya arsitektur arkeologi Islam, seperti halnya dijumpai pada beberapa situs serupa, bahwa ukuran gerbang kori agung (c) yang pendek berukuran $160 \mathrm{~cm}$ bertujuan agar orang yang melewati gerbang ini harus menunduk sebagai pertanda hormat (Tjandrasasmita, 1975: 16). Ditambah lagi keberadaan padasan (e) dan (f) di kedua sisi gerbang, yaitu guci tembikar tempat air yang secara simbolik menunjukkan bahwa siapa pun yang mau memasuki kompleks itu masuk dengan cara berhormat dan dalam keadaan suci. Pengunjung wajib mencuci kakinya dengan air dari padasan. Hal tersebut menjadi indikasi bagaimana halaman setelah melewati gerbang ini merupakan halaman yang sangat penting dan disucikan.

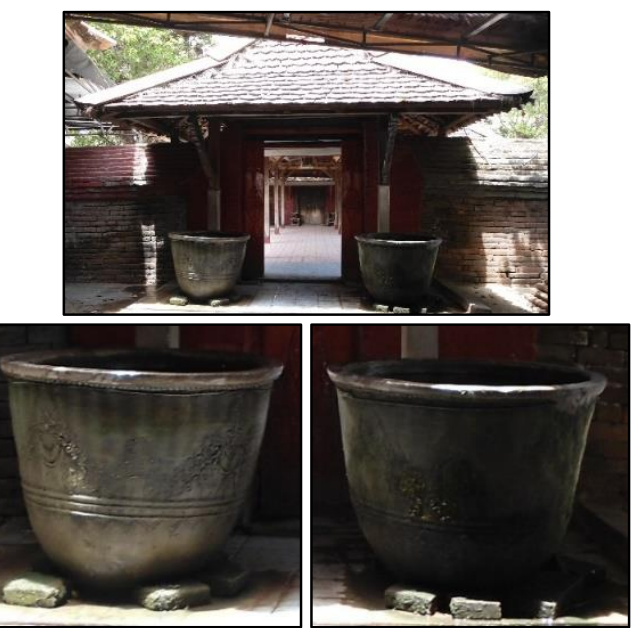

Gambar 14. Gerbang Kori Agung (c), padasan (e) dan (f)

(Sumber: Mujabuddawat, 2013)

Pada bagian sisi timur bangunan serambi masjid terdapat bangunan witana. Berdasarkan bentuknya, ditinjau dari segi fungsi sebuah bangunan, bangunan witana ini memiliki fungsi yang serupa dengan pendopo. Bangunan witana ini secara simbolik dipercaya dahulu merupakan bangunan yang didirikan oleh $\mathrm{Ki}$ Gede Trusmi untuk menyiarkan agama Islam. Bangunan-bangunan pendopo pada umumnya digunakan sebagai tempat berkumpul, bangunan pendopo banyak dijumpai di situssitus bangunan arkeologi Islam, dan menjadi ciri khas dari bangunan di Jawa. Tepat berhimpitan di sisi timur bangunan witana terdapat bangunan pekulahan. Sesuai bentuknya yang berupa kolam, pekulahan ini berfungsi sebagai sumber air yang digunakan untuk berwudhu dan keperluan lainnya. Air di dalam pekulahan seharusnya bersumber dari sungai kecil yang mengalir di sebelah timur kompleks situs, namun sekarang air yang terdapat di dalam pekulahan ialah air tanah (Mujabuddawat, 2013: 107).

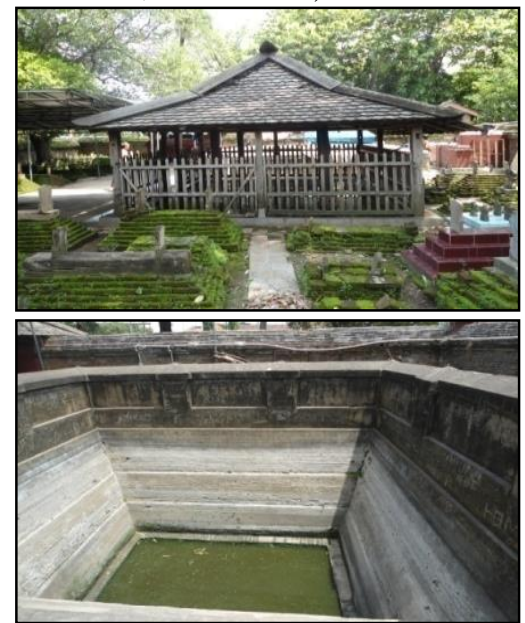

Gambar 15. Witana (atas) dan Pekulahan (bawah) (Sumber: Mujabuddawat, 2013)

Pada sisi sebelah utara pekulahan terdapat bangunan kuta hijab (b). Berdasarkan keletakan dan bentuknya, diketahui fungsi dari keberadaan kuta hijab (b) ini ialah sebagai penyekat yang berorientasi pada tata ruang dan keletakan bangunan-bangunan di area kompleks situs Ki Buyut Trusmi. Secara simbolik, kuta hijab (b) ini dibangun untuk menahan roh jahat agar tigak bisa memasuki situs. Keberadaan kuta hijab (b) ini juga agar pandangan orang dari luar tidak bisa melihat bagian dalam situs. Bentuk kuta hijab (b) yang lebih sederhana dibanding kuta hijab (a) menunjukkan bahwa terdapat perbedaan tingkatan kesucian dengan dunia luar setelah melewati kuta hijab (b) dan gerbang kori agung (b) yang juga bentuknya lebih sederhana dari gerbang kori agung (a). Didukung oleh ketidak beradaan padasan di gerbang kori agung (b) ini secara simbolik merupakan gerbang keluar kompleks situs menuju dunia luar.

Tepat sejajar dengan sisi sebelah timur kuta hijab (b) terdapat gerbang kori agung (b). Berdasarkan keletakan dan bentuknya, gerbang kori agung (b) merupakan pintu keluar kompleks situs Ki Buyut Trusmi. Hal tersebut ditunjukkan oleh ketidak-beradaan padasan di sekitar gerbang kori agung (b), maka hal tersebut menunjukkan bahwa gerbang ini merupakan gerbang keluar karena pada saat keluar meninggalkan area kompleks situs tidak 
perlu bersuci karena area di luar situs bukan area suci seperti area kompleks situs Ki Buyut Trusmi.

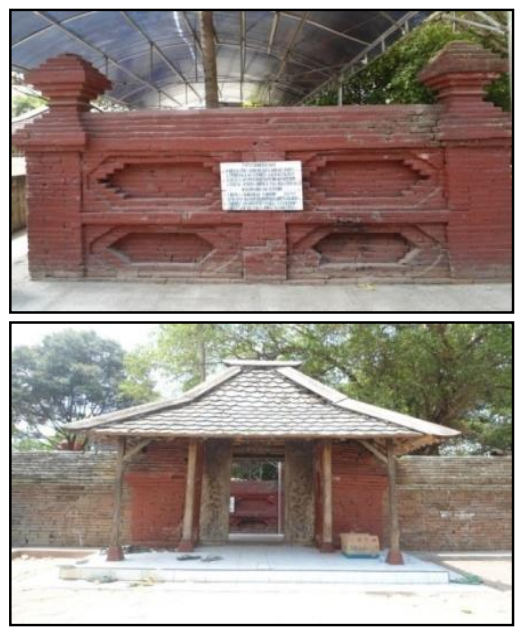

Gambar 16. Kuta Hijab (b) (atas) dan Kori Agung (b) (bawah)

(Sumber: Mujabuddawat, 2013)

Secara keseluruhan, Halaman timur situs ini merupakan halaman yang menaungi objek benda dan bangunan yang berfungsi sebagai komponen pelengkap kompleks situs. Berdasarkan makna fungsi dan makna simbolik yang ditunjukkan oleh setiap objek benda dan bangunannya, secara keseluruhan Halaman timur ini merupakan halaman yang menjadi alur penghubung dari Halaman barat ke Halaman tengah dan juga menjadi alur keluar kompleks situs. Keberadaan objek benda dan bangunan di Halaman timur ini tidak memiliki fungsi sebagai tempat tujuan utama pengunjung. Halaman timur ini terkesan sebagai halaman singgah bagi pengunjung yang hendak menuju halaman tengah atau keluar kompleks situs.

Tabel 5. Fungsi dan Makna Simbolik Bangunan di Halaman timur

\begin{tabular}{lll}
\hline No & Bangunan & Fungsi \& Makna simbolik \\
\hline 1 & $\begin{array}{l}\text { Gerbang } \\
\text { kori agung } \\
\text { (b) }\end{array}$ & $\begin{array}{l}\text { Pintu keluar area keruangan kompleks } \\
\text { situs }\end{array}$ \\
\cline { 3 - 3 } & & $\begin{array}{l}\text { Tidak terdapat padasan menandakan } \\
\text { orientasi gerbang menuju keluar } \\
\text { kompleks situs karena dunia luar bukan } \\
\text { area yang disucikan }\end{array}$ \\
\hline 2 & Kuta hijab & $\begin{array}{l}\text { Sebagai penyekat untuk menghalangi } \\
\text { pandangan orang di luar situs }\end{array}$ \\
\cline { 3 - 3 } & (b) & $\begin{array}{l}\text { Penyekat gerbang keluar yaitu gerbang } \\
\text { kori agung (b) yang menyambungkan } \\
\text { area yang disucikan atau dikeramatkan } \\
\text { dengan dunia luar begitu melewati kuta } \\
\text { hijab (b) sebagai penangkal roh jahat }\end{array}$ \\
\hline 3 & Pekulahan & $\begin{array}{l}\text { Sebagai sumber air yang digunakan } \\
\text { untuk berwudhu dan keperluan lainnya }\end{array}$ \\
\hline
\end{tabular}

\begin{tabular}{|c|c|c|}
\hline & & $\begin{array}{l}\text { Keletakannya di sisi timur situs } \\
\text { menunjukkan tingkat kesucian dari } \\
\text { pekulahan ini tidak sesakral area-area } \\
\text { di sebelah barat dan utara komleks } \\
\text { situs Ki Buyut Trusmi }\end{array}$ \\
\hline \multirow[t]{2}{*}{4} & \multirow[t]{2}{*}{$\begin{array}{l}\text { Ruang } \\
\text { serambi } \\
\text { masjid }\end{array}$} & $\begin{array}{l}\text { Sebagai perluasan dari bangunan ruang } \\
\text { utama masjid tempat umat Islam } \\
\text { beribadah }\end{array}$ \\
\hline & & $\begin{array}{l}\text { Keberadaan masjid di dalam area situs } \\
\text { kabuyutan secara simbolik } \\
\text { menunjukkan bahwa situs kabuyutan } \\
\text { ini merupakan situs besar yang } \\
\text { diagungkan }\end{array}$ \\
\hline \multirow[t]{2}{*}{5} & \multirow[t]{2}{*}{ Witana } & Sebagai tempat berkumpul \\
\hline & & $\begin{array}{l}\text { Bangunan yang didirikan oleh Ki Gede } \\
\text { Trusmi untuk menyiarkan agama Islam }\end{array}$ \\
\hline \multirow[t]{2}{*}{6} & \multirow{2}{*}{$\begin{array}{l}\text { Gerbang } \\
\text { Kori Agung } \\
\text { (c) }\end{array}$} & $\begin{array}{l}\text { Pintu masuk halaman tengah kompleks } \\
\text { situs }\end{array}$ \\
\hline & & $\begin{array}{l}\text { Menunduk ketika melewati gerbang } \\
\text { yang pendek sebagai pertanda hormat, } \\
\text { membasuh kaki dengan air dari } \\
\text { padasan (e) dan (f) menandakan } \\
\text { halaman tengah lebih suci } \\
\text { dibandingkan halaman timur }\end{array}$ \\
\hline
\end{tabular}

Fungsi dan Makna Simbolik Bangunan di Halaman tengah

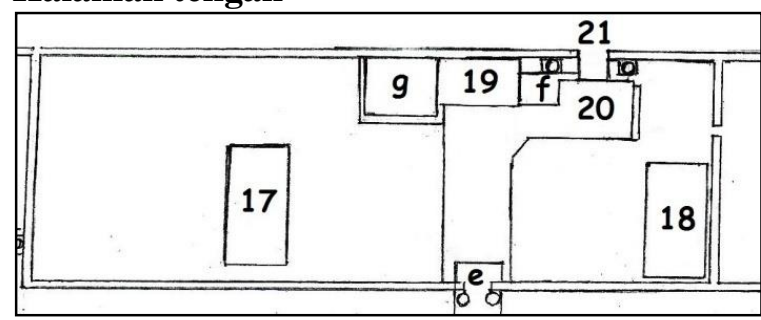

Gambar 17. Keletakan sebaran bangunan Halaman tengah

(Sumber: Mujabuddawat: 2013)

Area Halaman tengah terdiri atas objek bangunan sebagai berikut.

Tabel 6: Bangunan halaman tengah Situs

\begin{tabular}{ll}
\hline No & Bangunan \\
\hline 1 & Gerbang kori agung (d) \\
\hline 2 & Jinem wetan \\
\hline 3 & Jinem kulon \\
\hline 4 & Ruang peziarah \\
\hline 5 & Bale pesalinan \\
\hline Sumber: & Mujabuddawat, 2013
\end{tabular}

Setelah melewati gerbang kori agung (c) dan memasuki Halaman tengah situs, maka akan dihadapkan pada alur koridor memanjang ke arah utara hingga bangunan bale pesalinan, ruang peziarah, dan gerbang kori agung (d). Begitu memasuki halaman tengah situs, terdapat bangunan jinem wetan dan jinem kulon di sebelah timur dan barat Halaman tengah situs. Bangunan jinem wetan dan jinem kulon berdekatan dengan gerbang kori agung (c) yang 
tersambung ke Halaman utara atau ruang makam Ki Buyut Trusmi oleh koridor yang banyak diziarahi oleh peziarah, sehingga fungsi kedua bangunan ini diketahui merupakan bangunan yang didirikan untuk menaungi pengunjung yang berziarah. Secara simbolik, kedua bangunan ini memiliki makna sebagai tahap persiapan sebelum memasuki ruang peziarah lalu melewati gerbang kori agung (d) menuju ruang makam keramat $\mathrm{Ki}$ Buyut Trusmi.

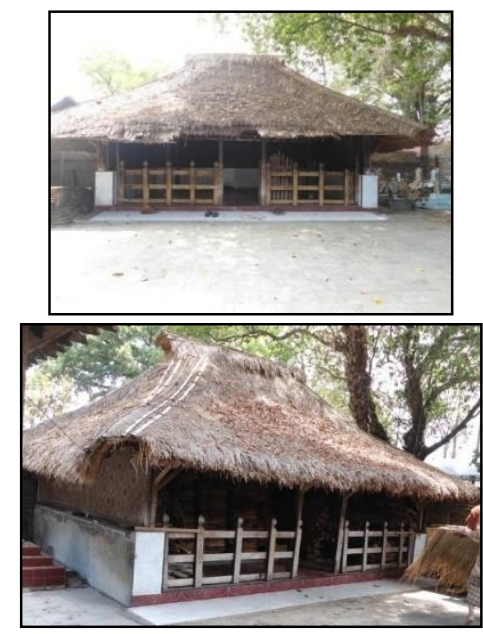

Gambar 18. Jinem kulon (atas) dan Jinem wetan (bawah)

(Sumber: Mujabuddawat, 2013)

Setelah mengikuti alur koridor terus ke arah utara, maka akan dihadapkan pada bangunan bale pesalinan. Berdasarkan namanya, 'bale pesalinan' berarti balai tempat menyimpan dan mengganti pakaian. Bangunan bale pesalinan ini berfungsi sebagai tempat para Juru Kunci atau Kuncen berganti pakaian dengan pakaian-pakaian adat khusus yang berada di dalam bangunan bale pesalinan ini. Bangunan bale pesalinan ini yang terkunci rapat dan tidak memiliki ventilasi secara simbolik menunjukkan sangat disucikan dan eksklusif. Ukuran pintu yang setinggi $140 \mathrm{~cm}$ membuat orang yang akan melewatinya harus menunduk secara simbolik menunjukkan penghormatan.

Tepat menempel dengan sisi sebelah barat bangunan bale pesalinan, adalah pagar tembok pembatas watu pendadaran. Watu pendadaran ialah kerakal berbentuk bulat yang disusun melingkar setengah lingkaran. Kerakal tersebut disusun berjejer dari yang berukuran paling besar hingga paling kecil . Pada bagian tengahnya terdapat satu buah kerakal yang memiliki ukuran paling besar (Mujabuddawat, 2013: 114). Kerakal tersebut berjumlah 17 buah, yang menurut kisah lokal merupakan peninggalan Buyut Trusmi dan memiliki makna yang melambangkan jumlah rokaat dalam tuntunan sholat fardhu. Watu pendadaran ini difungsikan sebagai ungkapan akan tinggalan $\mathrm{Ki}$ Buyut Trusmi mengenai ajaran sekaligus pengingat sholat fardhu yang harus dilaksanakan.

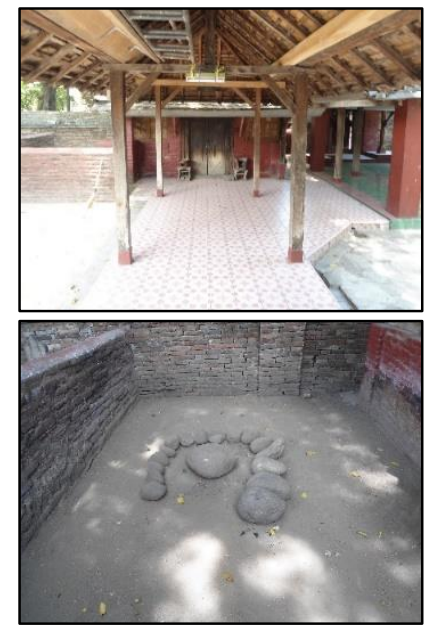

Gambar 19. Lorong Koridor menuju Bale Pesalinan (atas), Batu Pendadaran (bawah), Ruang Peziarah (kanan)

(Sumber: Mujabuddawat, 2013)

Pada sisi sebelah timur bangunan bale pesalinan terdapat bangunan ruang peziarah yang memiliki cungkub yang menempel dengan bale pesalinan. Berdasarkan keletakan dan bentuknya, maka dapat diketahui bahwa bangunan ruang peziarah ini berfungsi sebagai ruang tunggu yang menaungi para peziarah sebelum memasuki gerbang kori agung (d) menuju ruang makam keramat $\mathrm{Ki}$ Buyut Trusmi. Hal tersebut ditunjukkan oleh keletakan bangunan ini yang berada persis di depan gerbang kori agung (d). Tepat menempel dengan cungkub ruang peziarah terdapat bangunan gerbang kori agung (d). Berdasarkan keletakannya, dapat diketahui gerbang kori agung (d) merupakan pintu yang menyambungkan antara Halaman tengah dengan Halaman utara situs yang merupakan ruang makam keramat Ki Buyut Trusmi. Tepat di depan gerbang kori agung (d) terdapat padasan (g) dan (h). Berdasarkan fungsi padasan yang terdapat pada bangunanbangunan Islam kuno di Jawa, padasan ini 
berfungsi sebagai tempat air wudhu atau membersihkan diri.

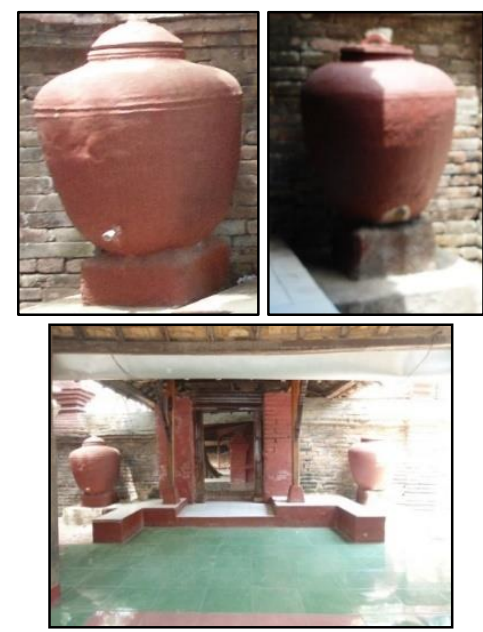

Gambar 20. Padasan (g) \& padasan (h) (atas), Ruang Peziarah menuju kori agung (d) (bawah) (Sumber: Mujabuddawat, 2013)

Gerbang kori agung (d) memiliki bentuk yang serupa dengan gerbang kori agung (a), (b), dan (c). Dari segi makna simbolik gaya arsitektur arkeologi Islam, seperti halnya dijumpai pada beberapa situs serupa, bahwa ukuran gerbang kori agung (d) yang pendek berukuran $165 \mathrm{~cm}$ bertujuan agar orang yang melewati gerbang ini harus menunduk sebagai pertanda hormat (Tjandrasasmita, 1975: 16). Ditambah lagi keberadaan padasan $(\mathrm{g})$ dan $(\mathrm{h})$ di kedua sisi gerbang, yaitu wadah tembikar tempat air yang secara simbolik bahwa siapa pun yang mau memasuki kompleks itu masuk dengan cara berhormat dan dalam keadaan suci. Pengunjung wajib mencuci kakinya dengan air dari padasan. Hal tersebut menjadi indikasi bagaimana ruang setelah melewati gerbang ini merupakan ruang yang sangat penting dan disucikan.

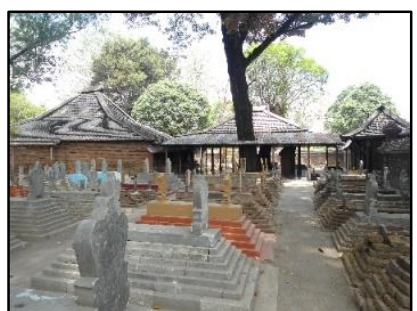

Gambar 21. Halaman utara Situs, Cungkub Makam Ki Gede Trusmi (kiri)

(Sumber: Mujabuddawat, 2013)

Berdasarkan fungsi dan makna simbolik dari setiap objek benda dan bangunan yang terhimpun di dalam area Halaman tengah ini, secara simbolik menjadikannya sebagai halaman singgah dan berkumpulnya pengunjung dalam rangka mempersiapkan diri untuk berziarah ke Halaman utara situs atau halaman makam keramat Ki Buyut Trusmi.

Tabel 7. Fungsi dan Makna Simbolik Bangunan di Halaman tengah

\begin{tabular}{|c|c|c|}
\hline No & Bangunan & Fungsi \& Makna simbolik \\
\hline \multirow[t]{2}{*}{1} & \multirow[t]{2}{*}{$\begin{array}{l}\text { Gerbang kori } \\
\text { agung }(d)\end{array}$} & $\begin{array}{l}\text { Pintu masuk menuju area ruang makam } \\
\text { keramat Ki Buyut Trusmi }\end{array}$ \\
\hline & & $\begin{array}{l}\text { Menunduk ketika melewati gerbang yang } \\
\text { pendek sebagai pertanda hormat, } \\
\text { membasuh kaki dengan air dari padasan } \\
\text { menandakan kesucian ruang di balik } \\
\text { gerbang ini }\end{array}$ \\
\hline \multirow[t]{3}{*}{2} & \multirow{3}{*}{$\begin{array}{l}\text { Bale } \\
\text { pesalinan }\end{array}$} & Sebagai tempat para Juru Kunci atau \\
\hline & & $\begin{array}{l}\text { Kuncen berganti pakaian dengan pakaian- } \\
\text { pakaian adat khusus }\end{array}$ \\
\hline & & $\begin{array}{l}\text { Bangunan bale pesalinan ini terkunci } \\
\text { rapat dan tidak memiliki ventilasi secara } \\
\text { simbolik menunjukkan sangat disucikan } \\
\text { dan eksklusif. Ukuran pintu yang pendek } \\
\text { membuat orang yang akan melewatinya } \\
\text { harus menunduk secara simbolik } \\
\text { menunjukkan penghormatan }\end{array}$ \\
\hline \multirow[t]{2}{*}{3} & \multirow[t]{2}{*}{$\begin{array}{l}\text { Ruang } \\
\text { peziarah }\end{array}$} & $\begin{array}{l}\text { Sebagai ruang tunggu yang menaungi } \\
\text { para peziarah sebelum memasuki } \\
\text { gerbang kori agung }(\mathrm{d}) \text { menuju ruang } \\
\text { makam keramat Ki Buyut Trusmi }\end{array}$ \\
\hline & & $\begin{array}{l}\text { Bangunanyang menaungi peziarah untuk } \\
\text { persiapan terakhir sebelum melakukan } \\
\text { ziarah di area makam keramat Ki Buyut } \\
\text { Trusmi }\end{array}$ \\
\hline 4 & Jinem wetan & $\begin{array}{l}\text { Sebagai ruang tunggu dan istirahat para } \\
\text { peziarah }\end{array}$ \\
\hline 5 & Jinem kulon & $\begin{array}{l}\text { Sebagai ruang tunggu dan istirahat para } \\
\text { peziarah }\end{array}$ \\
\hline \multirow[t]{2}{*}{6} & \multirow[t]{2}{*}{$\begin{array}{l}\text { Watu } \\
\text { pendadaran }\end{array}$} & $\begin{array}{l}\text { Kerakal bersusun } 17 \text { buah, yang menurut } \\
\text { kisah lokal merupakan peninggalan Buyut } \\
\text { Trusmi dan memiliki makna yang } \\
\text { melambangkan jumlah rokaat dalam } \\
\text { tuntunan sholat fardhu. } \\
\text { Watu pendadaran dibatasi dan dipagari }\end{array}$ \\
\hline & & $\begin{array}{l}\text { oleh tembok bata mengindikasikan } \\
\text { bahwa watu pendadaran ini merupakan } \\
\text { bagian penting di dalam aspek keruangan } \\
\text { kompleks situs ini yang berarti harus } \\
\text { dijaga keberadaannya. }\end{array}$ \\
\hline
\end{tabular}

\section{Makna Simbolik Denah Tata Letak Bangunan Ki Buyut Trusmi}

Berdasarkan uraian dan tinjauan yang mencakup aspek keletakan, bentuk, fungsi dan makna simbolik dari setiap objek benda dan bangunan yang terdapat di dalam aspek keruangan kompleks situs ini, maka dapat ditemukan kesimpulan dari keterkaitan fungsi yang terhubung dengan objek-objek tersebut. Keterkaitan antar objek benda dan bangunan membentuk alur dari tata letak objek-objek 
tersebut di dalam area keruangan kompleks situs Ki Buyut Trusmi. Alur tata letak ini maksudnya adalah suatu alur pencapaian yang harus ditempuh pengunjung menuju lokasi utama yang dituju, yaitu makam $\mathrm{Ki}$ Gede Trusmi dan Pangeran Trusmi di Halaman utara situs.

Gerbang kori agung (a) yang merupakan gerbang masuk utama kompleks situs. Pada bagian samping kiri dan kanan grerbang kori agung terdapat padasan, yaitu wadah tembikar tempat air dan gayungnya yang secara simbolik bahwa siapa pun yang mau memasuki kompleks itu masuk dengan cara berhormat dan dalam keadaan suci. Pengunjung wajib melepas alas kaki sebelum memasuki kompleks situs dan mencuci kakinya dengan air dari padasan. Prosesi mensucikan diri seperti itu secara simbolik menunjukkan bahwa suatu ruang atau area dibalik gerbang yang akan dilewati merupakan area yang lebih suci. Setelah melewati gerbang kori agung (a), maka akan dihadapkan pada kuta hijab (a) atau tembok pemisah, kuta hijab ini secara simbolik menyekat antara gerbang masuk yaitu gerbang kori agung (a) yang menyambungkan dunia luar dengan area yang disucikan atau dikeramatkan begitu melewati kuta hijab (a). Keberadaan kuta hijab (a) ini secara simbolis sebagai sekat yang menangkal roh jahat dan menghalangi pandangan mata yang melihat dari luar gerbang kori agung (a), artinya secara simbolis area Halaman barat lebih suci dibandingkan dunia luar.

Alur berikutnya ialah memasuki area Halaman timur situs. Halaman timur situs memiliki tingkat kesucian yang sama dengan Halaman barat Situs, karena untuk memasuki area ini tidak melewati gerbang kori agung dan tidak ada padasan untuk bersuci. Halaman timur situs merupakan area untuk melaksanakan ibadah karena pintu masjid terletak di Halaman timur situs, secara simbolis pengunjung diharapkan mengingat Illahi terlebih dahulu sebelum menuju lokasi utama, yaitu Makam Ki Gede Trusmi dan Pangeran Trusmi di Halaman utara situs. Gerbang kori agung (c) menghubungkan Halaman timur dengan Halaman tengah situs Ki Buyut Trusmi. Pada gerbang kori agung (c) ini terdapat padasan di kedua sisi daun pintunya yang secara simbolik memiliki arti bahwa sebelum memasuki ruang dibalik gerbang kori agung (c), pengunjung harus bersuci terlebih dahulu. Ukuran pintu gerbang yang berukuran tinggi $160 \mathrm{~cm}$ membuat pengunjung harus menunduk untuk melewatinya yang secara simbolik bermakna pertanda hormat. Secara simbolis, Halaman tengah lebih suci dibandingkan dengan Halaman timur situs.

Berdasarkan keberadaan komponen bangunannya, Halaman tengah situs merupakan ruang untuk persiapan menuju lokasi utama di Halaman utara situs, yaitu Makam Ki Gede Trusmi dan Pangeran Trusmi. Pada Halaman tengah inilah terdapat gerbang kori agung (d) yang terhubung ke Halaman utara situs. Bentuk gerbang kori agung (d) serupa dengan gerbang kori agung (c), terdapat padasan di kedua sisi daun pintunya yang secara simbolik memiliki arti bahwa sebelum memasuki ruang dibalik gerbang kori agung (d), pengunjung harus bersuci terlebih dahulu. Ukuran pintu gerbang yang berukuran tinggi $165 \mathrm{~cm}$ membuat pengunjung harus menunduk untuk melewatinya yang secara simbolik bermakna pertanda hormat, secara simbolis Halaman utara situs ini merupakan lokasi akhir yang dituju untuk mencapai makam Ki Gede Trusmi dan Pangeran Trusmi yang menjadi halaman paling suci dibandingkan halaman lainnya. Posisi penataan peletakan makam tokoh utama di paling timur, paling utara, atau paling terdepan dari makam-makam lain di sekitarnya dimaksud untuk menghindari bagian kepala yang dianggap suci. Selain itu ada kalanya makam tokoh utama diletakkan pada satu ruangan atau dalam bangunan cungkup tersendiri yang diberi pagar atau ditembok keliling yang terpisah dengan makam lain (Latifundia, 2013a: 140141).

Pada alur keluar kompleks situs, pengunjung akan mengikuti alur menuju arah timur. Saat mengikuti alur keluar, pengunjung akan dihadapkan pada bangunan kuta hijab (b). Kuta hijab ini menyekat antara gerbang keluar yaitu gerbang kori agung (b) yang menyambungkan dunia luar. Seperti halnya kuta hijab (a), berdasarkan konteks fungsi yang berorientasi dengan gerbang kori agung (b) yang secara konsep alur tata keletakan, gerbang kori agung (b) merupakan gerbang keluar dari kompleks situs Ki Buyut Trusmi. Maka fungsi dari keberadaan kuta hijab (b) ini ialah sebagai penyekat gerbang keluar yaitu gerbang kori agung (b) yang menyambungkan area yang 
disucikan atau dikeramatkan dengan dunia luar begitu melewati kuta hijab (b) ini. Setelah melewati kuta hijab (b), maka pengunjung akan dihadapkan pada gerbang kori agung (b). Gerbang kori agung (b) memiliki bentuk yang serupa dengan gerbang kori agung (a), namun di gerbang kori agung (b) tidak terdapat padasan. Ketiadaan padasan mendukung fungsi keberadaan gerbang kori agung (b) sebagai gerbang keluar situs, karena dunia luar bukanlah area suci sehingga pengunjung tidak perlu bersuci ketika keluar dari kompleks situs Ki Buyut Trusmi.

Berdasarkan keletakan, fungsi, dan makna simbolik yang dimiliki oleh tiap-tiap objek benda dan bangunan telah membentuk suatu alur tak tampak dalam area keruangan kompleks situs Ki Buyut Trusmi. Secara garis besar, alur tersebut tergambar pada gambar berikut ini.

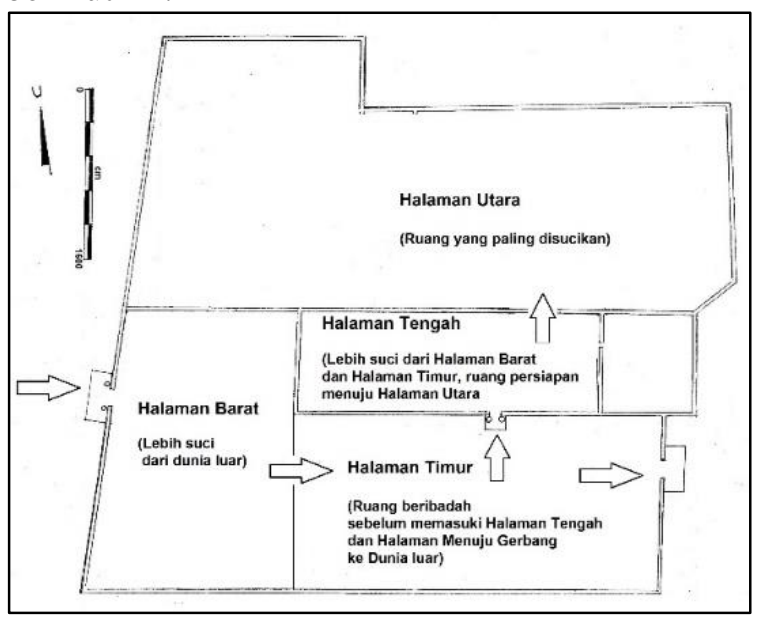

Gambar 22. Denah Alur Situs

(Sumber: Mujabuddawat 2016)

\section{KESIMPULAN}

Denah tata letak bangunan-bangunan di dalam situs Ki Buyut Trusmi tampak seolaholah komposisinya mengikuti aturan-aturan jarak seperti pada bentuk arsitektur Hindu. Pada kompleks situs Ki Buyut Trusmi, pokok-pokok pembentukan komposisi dalam teknis keletakan bangunan-bangunan adalah adanya temboktembok penyekat, keberadaan bangunan, dan keberadaan tanaman halaman. Tembok penyekat memberikan kesan sebagai pemisah secara tegas antar ruang. Sementara itu, keberadaan bangunan seperti masjid, paseban, bale pakuncen, pewadonan, dan lainnya merupakan bangunan yang dipisah menurut kesesuaian komposisi alur dan fungsi bangunan. Tembok penyekat memberikan kesan pemisahan fungsi dan alur yang jelas menuju tempat tujuan dalam kompleks situs.

Berdasarkan hasil pembahasan, dijelaskan bangunan-bangunan yang berdiri di dalam area kompleks situs memiliki fungsi dan makna simbolik tersendiri. Berdasarkan makna simbolik yang ditemukan, serta ratusan makam yang tersebar di dalam area situs tampak jelas menunjukkan percampuran antara bangunan Islam yang terbawa pengaruh budaya lokal yang sebelumnya telah ada, yaitu animisme dan Hindu-Budha. Budaya lokal yang mencirikan budaya pra-Islam seperti bentuk penghormatan dengan cara menundukkan badan kepada suatu tokoh yang dihormati atau dituakan serta perlakuan berlebihan atau pemujaan kepada makam-makam yang dianggap keramat diwujudkan dalam bentuk bangunan gerbang kori agung dan lawang kepundungan. Kepercayaan lokal terhadap roh jahat diwujudkan dalam bangunan kuta hijab yang dipercaya untuk menangkal roh jahat masuk ke dalam area situs. Budaya lokal yang bersuci sebelum memasuki tempat keramat diwujudkan dengan keberadaan padasan. Perilaku-perilaku tersebut pada hakikatnya tidak terdapat dalam ajaran Islam. Kepercayaan Percampuran tersebut membentuk khasanah budaya materi pra Islam berujud pada arsitektur bangunan yang sarat akan simbolisme di luar syariat Islam yang sesungguhnya.

Simbolisme dari denah tata letak kompleks situs dapat dilihat dari pembagian halaman menjadi 4 halaman dengan tingkat kesucian yang berbeda. Keletakan komponenkomponen bangunannya secara simbolis membentuk denah alur menuju lokasi utama yang paling disucikan, yaitu makam Ki Gede Trusmi dan Pangeran Trusmi di Halaman utara situs. Sebelum melewati gerbang kori agung di halaman barat yang merupakan pintu masuk area kompleks situs diwajibkan untuk melepas alas kaki dan membasuh kaki. Secara simbolik, hal ini menunjukkan bahwa area kompleks situs lebih suci dibandingkan dunia luar. Ketidakberadaan gerbang dan padasan saat memasuki halaman timur menandakan bahwa halaman timur memiliki tingkat kesucian yang sama dengan halaman barat. Keberadaan gerbang kori agung dan padasan saat memasuki area halaman tengah menandakan halaman tengah lebih suci dari halaman barat dan halaman 
timur. Keberadaan gerbang kori agung dan padasan sebelum memasuki area halaman utara menandakan halaman utara tingkatannya lebih suci dari halaman tengah, halaman barat, dan halaman timur. Dari segi denah tata letak kompleks situs menunjukkan makna simbolik bahwa halaman utara sebagai ruang yang paling dikeramatkan dan disucikan, karena untuk mencapai cungkub makam Ki Gede Trusmi dan Pangeran Trusmi di halaman utara harus melewati 3 halaman yang memiliki tingkat kesucian yang semakin tinggi.

Berdasarkan hasil pembahasan, tampak budaya lokal menjadi bagian konstruksi keIslaman masyarakat setempat. Islam yang berkembang pada khususnya di daerah Trusmi, Cirebon menunjukkan karakter Islam yang integratif dan akomodatif terhadap paham dan kepercayaan lokal masyarakat.

\section{Ucapan Terima Kasih}

Penulis mengucapkan terima kasih kepada kepada pihak-pihak terkait di Dinas Kebudayaaan dan Pariwisata dan Perpustakaan Umum Daerah Kab. Cirebon yang telah membantu dalam memperoleh sumber-sumber referensi. Penulis juga mengucapkan terima kasih kepada seluruh Kyai, Kuncen dan Juru Kunci di Kompleks Situs Ki Buyut Trusmi yang telah membantu penulis dalam memberikan informasi dan data lainnya selama tahap observasi. Semoga tulisan ini bermanfaat untuk menambah wawasan ilmu.

$$
* * * * *
$$

\section{DAFTAR PUSTAKA}

Ambary, H. M. (1998). Menemukan Peradaban, Arkeologi dan Islam di Indonesia. Jakarta: Pusat Penelitian Arkeologi Nasional.

Anonim. (1993). Keaneka Ragaman Bentuk Masjid di Jawa. Jakarta: Departemen Pendidikan dan Kebudayaan RI.

Casta, \& Taruna. (2007). Batik Cirebon: Sebuah Pengantar Apresiasi, Motif, dan Makna Simboliknya. Cirebon: Badan Komunikasi Kebudayaan dan Pariwisata Kabupaten Cirebon.

Darajat, Z. (2015). Warisan Islam Nusantara. AlTurāsi, XXI(1), 66-78.

Deetz, J. (1967). Invitation to Archaeology. Garden City, NY: Natural History Press.

Handoko, W. (2012). Perkembangan Islam di Pulau Ambalau: Kajian atas Data Arkeologi dan
Tradisi Makam Islam Berundak. Kapata Arkeologi, 8(1), 25-34.

Handoko, W. (2014). Tradisi Nisan Menhir pada Makam Kuno Raja-raja di Wilayah Kerajaan Hitu. Kapata Arkeologi, 10(1), 33-46.

Haris, T. (2010). Masjid-masjid di Dunia Melayu Nusantara. Suhuf, 3(2), 279-307.

Latifundia, E. (2013a). Makna Penataan Peletakan Makam Kuno di Tepi Sungai Cirende Kecamatan Sukadana-Ciamis. Purbawidya, 2(2), 131-141.

Latifundia, E. (2013b). Pengaruh Budaya Pra-Islam pada Makam di Desa Salakaria Kecamatan Sukadana - Ciamis. Purbawidya, 2(1), 12-24.

Latifundia, E. (2014). Nisan Kuno di Garawangi, Kuningan: Hubungannya dengan Islamisasi. Purbawidya, 3(2), 101-114.

Latifundia, E. (2015). Jejak Budaya pada Nisan Kuno Islam di Kuningan. Al-Turās, XXI(1), 30-41.

Muhaimin, A. G. (2006). The Islamic Traditions of Cirebon: Ibadah and Adat Among Javanese Muslims. Canberra: ANU E press.

Mujabuddawat, M. Al. (2013). Tinjauan Arkeologis Kompleks Situs Ki Buyut Trusmi Cirebon. Universitas Indonesia.

Mujabuddawat, M. Al. (2015). Kompleks Situs Ki Buyut Trusmi Cirebon: Tinjauan Bangunan Kuno. Kapata Arkeologi, 11(2), 139-154.

Muliawan, A. (2008). Mengenal Lebih dekat 161 Situs di Kabupaten Cirebon. Cirebon: Badan Komunikasi Kebudayaan dan Pariwisata Kabupaten Cirebon.

Saptono, N. (2013). Perubahan Kebudayaan pada Masa Transisi Pra-Islam ke Islam di Sumedang. Purbawidya, 2(2), 182-197.

Saringendyanti, E. (1998). Penempatan Situs Upacara Masa Hindu-Buda: Kajian Lingkungan Fisik Kabuyutan di Jawa Barat. Universitas Indonesia.

Soekatno, T. W. (1981). Daftar Inventaris Peninggalan Sejarah dan Purbakala (benda tak bergerak) Jilid III. Jakarta: Departemen Pendidikan dan Kebudayaan RI.

Tjandrasasmita, U. (1975). Islamic Antiquities of Sendang Duwur. Jakarta: Pusat Penelitian Arkeologi Nasional.

Tjandrasasmita, U. (1976). Sepintas Mengenai Peninggalan Kepurbakalaan Islam di Pesisir Utara Jawa. Jakarta: Pusat Penelitian Arkeologi Nasional. 